\title{
Selective Elevation of Systemic Blood Pressure by Epinephrine during Sepsis-Induced Pulmonary Hypertension in Piglets
}

\author{
WILLIAM L. MEADOW, BRIAN F. RUDINSKY, AND ELENE STRATES
}

Department of Pediatrics, Wyler Children's Hospital, The University of Chicago, Chicago, Illinois 60637

\begin{abstract}
In a piglet model of group B $\beta$ Streptococci (GBS)-induced pulmonary hypertension, we have determined hemodynamic responses to epinephrine (EPI) infusion in both the systemic and pulmonary circulations. Three groups of piglets (GBS + EPI, $n=6$; GBS + placebo, $n=6$; placebo, $n=6$ ) were studied. GBS, infused intravenously at $\sim 5 \times 10^{7}$ organisms $/ \mathrm{kg} / \mathrm{min}$, reduced cardiac index and stroke volume index while elevating pulmonary artery pressure and pulmonary vascular resistance index. Systemic vascular resistance index, heart rate and aortic pressure did not change during GBS infusion. Six piglets received intravenous EPI after cardiac index had fallen by $30 \%$ during GBS infusion. At 3.5, 7.0, and $15 \mu \mathrm{g} / \mathrm{kg} / \mathrm{min}$, respectively, EPI raised aortic pressure by $18.5,31.0$, and $45.0 \mathrm{~mm} \mathrm{Hg}$ while EPI reduced pulmonary artery pressure by $5.2,6.3$, and $8.2 \mathrm{~mm} \mathrm{Hg}$. At each dose, EPI elevated systemic vascular resistance index and lowered pulmonary vascular resistance index. At $3.5 \mu \mathrm{g} / \mathrm{kg} /$ min, the elevation of aortic pressure was associated with an increase in both cardiac index and systemic vascular resistance index. At higher EPI doses, the rise in aortic pressure was accounted for entirely by an increase in systemic vascular resistance index. Systemic acid/base status and $\mathrm{PaO}_{2}$ did not differ among piglets who received GBS + EPI, GBS alone, or placebo. Extrapolation of these data to human infants must be approached with extreme caution. However, selective elevation of systemic blood pressure may be a feasible strategy for some infants to impede right-to-left shunting of blood often associated with sepsis-induced pulmonary hypertension. (Pediatr Res 20: 872-875, 1986)
\end{abstract}

\section{Abbreviations}

EPI, epinephrine

GBS, group B $\beta$ hemolytic Streptococci

D5/LR, 5\% dextrose lactated Ringer's solution

PAP, pulmonary artery pressure

AOP, aortic blood pressure

PVR, pulmonary vascular resistance

SVR, systemic vascular resistance

PVRI, pulmonary vascular resistance index

SVRI, systemic vascular resistance index

HR, heart rate

$\mathrm{CO}$, cardiac output

CI, cardiac index

$\mathrm{SV}$, stroke volume

Received May 20, 1985; accepted April 28, 1986.

Address for Correspondence and reprint requests William L. Meadow, M.D., Ph.D., Department of Pediatrics-Box 325, Wyler Children's Hospital, The University of Chicago, 5825 S. Maryland Avenue, Chicago, IL 60637.

This work was supported in part by funds from the Children's Research Foundation of Chicago.
SVI, stroke volume index

CVP, central venous pressure

The transition from in utero to ex utero existence is generally accompanied by a significant fall in PAP and PVR (1-3). Under certain circumstances, however, PAP and PVR remain elevated after birth, and persistent pulmonary hypertension may be associated with considerable derangement of cardiopulmonary dynamics in the newborn. If PAP is elevated to levels approaching AOP, blood may be shunted directly from the venous to arterial circulations, resulting in hypoxemia (1-4).

Consequently, many investigators including ourselves, have attempted to identify techniques to reduce PAP and PVR selectively; that is, to effect a fall in PAP greater than a concomitant fall in AOP for any given intervention (4-7). We have developed a model of sepsis-induced pulmonary hypertension using infusion of GBS in piglets and have attempted to determine hemodynamic correlates of pathologically elevated PAP utilizing techniques not widely available clinically $(7,8)$.

In our piglet model of sepsis-induced pulmonary hypertension, we have been unable to demonstrate any agent currently approved for use in human newborns which reduces PAP and PVR to a greater extent than it lowers AOP and SVR. Others, using lambs with hypoxia-induced pulmonary hypertension, have also been unable to demonstrate such an agent $(5,6,9,10)$. Nor, in human newborns with pulmonary hypertension, has any selective pulmonary vasodilator consistently been identified.

As an alternative approach, we investigated the possibility that selective elevation of AOP and SVR, without an equal concurrent rise in PAP and PVR, might be achieved in the context of sepsisinduced pulmonary hypertension. We report here that EPI raised AOP without increasing PAP in piglets whose PA pressures had previously been elevated with GBS. This selective elevation of $\mathrm{AOP}$ was achieved without a significant decrease in $\mathrm{CO}$.

\section{MATERIALS AND METHODS}

Surgical preparation. Eighteen piglets, Sus scrofa, 1-4 wk old were administered ketamine intraperitoneally $(20 \mathrm{mg} / \mathrm{kg})$, intubated endotracheally, and anaesthetized with sodium pentobarbital $(20 \mathrm{mg} / \mathrm{kg}$ initially, $2 \mathrm{mg} / \mathrm{kg}$ subsequently). Muscle relaxation was achieved with curare $(1 \mathrm{mg} / \mathrm{kg})$. Mechanical ventilation (Harvard Medical Supplies, Dover, MA) was adjusted to maintain $\mathrm{PaCO}_{2}$ at 25-35 torr during the entire experiment. Warming blankets and heating lamps were used to maintain rectal temperature at $37-38^{\circ} \mathrm{C}$. A suprapubic cystostomy catheter was placed to establish urinary drainage in the paralyzed animal.

Polyethylene catheters providing venous access were introduced surgically into the internal and external jugular veins. 
Pressure catheters were placed in the aorta (via femoral artery), right atrium (via internal jugular vein), and PA (via left lateral thoracotomy). An external electromagnetic flow probe (Carolina Medical Electronics, King, NC) was placed around the PA, proximal to the tip of the PA catheter. During each experiment, the signal from the PA flow probe was adjusted continuously using the approximation that diastolic PA blood flow was zero.

Hemodynamic monitoring. Five hemodynamic parameters were measured directly and continuously: HR, phasic and mean AOP, phasic and mean PAP, phasic and mean CVP, and phasic and mean pulmonary artery blood flow. Pulmonary artery blood flow was taken as equivalent to $\mathrm{CO}$ in the documented absence of left-to-right or right-to-left vascular shunts. These shunts were precluded by comparisons of oxygen saturation in blood samples from the right atrium, pulmonary artery, and aorta.

$\mathrm{CO}$ was divided by body weight to obtain CI. SVI was calculated as the ratio of CI/HR. SVRI was calculated as the ratio of (AOP-CVP)/CI. PVRI was estimated as the ratio of PAP/CI. Arterial blood gases were obtained twice during the baseline period prior to the onset of GBS infusion, and once at the completion of the experiment. Baseline hemodynamic observations were begun $1 \mathrm{~h}$ after the completion of surgery.

Preparation of bacteria. GBS serotype $1 \mathrm{~b}$, previously isolated from an infected human newborn, were grown in $250 \mathrm{ml}$ ToddHewitt broth to late log phase $\left(\sim 1 \times 10^{9}\right.$ organisms/ml $)$. The bacteria were then centrifuged, the supernatant decanted, and the organisms resuspended to their original concentration in D5/ LR. Quantitative cultures of the bacterial inoculum were performed by serial dilution to allow retrospective calculation of the rate of bacterial infusion.

Experimental protocol. Three experimental groups were studied. Group 1 piglets (GBS + EPI; $n=6$ ) received continuous GBS infusion at $\sim 5 \times 10^{7}$ organisms $/ \mathrm{kg} / \mathrm{min}$ until $\mathrm{CO}$ had fallen by $30 \%$ compared to baseline. At that point, with the GBS infusion continuing, EPI was administered (first dose $=3.5 \mu \mathrm{g} /$ $\mathrm{kg} / \mathrm{min}$ intravenous, followed by 7 and $15 \mu \mathrm{g} / \mathrm{kg} / \mathrm{min}$ ) and hemodynamic observations were continued until a plateau response to each dose of EPI was achieved ( $c f$. Fig. 1). These doses of EPI were selected after preliminary experiments in our laboratory demonstrated that lower doses had little hemodynamic effect in septic piglets. Group 2 piglets (GBS + placebo; $n=6$ ) received GBS at $\sim 5 \times 10^{7}$ organisms $/ \mathrm{kg} / \mathrm{min}$ until $\mathrm{CO}$ had fallen by $30 \%$ compared to control. At that point, with the GBS infusion continuing, placebo infusion (D5/LR) was begun. Group 3 piglets (placebo; $n=6$ ) received D5/LR continuously. Hemodynamic observations for piglets in groups 2 and 3 were determined at times equal to the mean time of observations for group 1 animals (duration of GBS infusion $47 \pm 19$ (SD) min, duration of EPI infusion $26 \pm 9 \mathrm{~min}$ ).

Data presentation and statistical analysis. Data are expressed as mean $\pm \mathrm{SD}$. Absolute values of baseline hemodynamic variables are displayed in Table 1 for each experimental group. Hemodynamic effects of infusion of GBS, EPI, or placebo are expressed as absolute changes of each variable compared to its value prior to the onset of infusion (Tables 2 and 3). For piglets in group 1 , the change in each hemodynamic variable at each EPI dose was determined by comparison to the baseline value prior to the onset of EPI infusion.

Data were analyzed within and across experimental groups, using two independent statistical tests. Within each experimental group, the change of each hemodynamic variable after infusion of EPI, GBS, or placebo was analyzed using Student's paired $t$ test. Across the three experimental groups, changes in each hemodynamic variable after infusion of EPI, GBS, or placebo were analyzed using analysis of variance supplemented by StuTable 1. Baseline values in piglets [mean (SD)]

\begin{tabular}{|c|c|c|c|}
\hline & $\begin{array}{c}\text { Group 1 } \\
\text { GBS + EPI } \\
(n=6)\end{array}$ & $\begin{array}{c}\text { Group } 2 \\
\text { GBS + placebo } \\
(n=6)\end{array}$ & $\begin{array}{l}\text { Group } 3 \\
\text { placebo } \\
(n=6)\end{array}$ \\
\hline Wt $(\mathrm{kg})$ & $\begin{array}{c}6.2 \\
(4.2)\end{array}$ & $\begin{array}{c}6.8 \\
(2.4)\end{array}$ & $\begin{array}{c}4.5 \\
(1.5)\end{array}$ \\
\hline $\mathrm{AOP}(\mathrm{mm} \mathrm{Hg})$ & $\begin{array}{l}101.0 \\
(14.1)\end{array}$ & $\begin{array}{c}95.2 \\
(10.3)\end{array}$ & $\begin{array}{c}89.5 \\
(17.3)\end{array}$ \\
\hline $\mathrm{PAP}(\mathrm{mm} \mathrm{Hg})$ & $\begin{array}{l}12.2 \\
(5.7)\end{array}$ & $\begin{array}{l}13.2 \\
(3.1)\end{array}$ & $\begin{array}{l}13.8 \\
(5.4)\end{array}$ \\
\hline $\mathrm{CI}(\mathrm{ml} / \mathrm{min} / \mathrm{kg})$ & $\begin{array}{l}150 \\
(47)\end{array}$ & $\begin{array}{l}118 \\
(25)\end{array}$ & $\begin{array}{l}115 \\
(42)\end{array}$ \\
\hline HR (beats/min) & $\begin{array}{l}174 \\
(52)\end{array}$ & $\begin{array}{l}139 \\
(24)\end{array}$ & $\begin{array}{l}160 \\
(36)\end{array}$ \\
\hline $\mathrm{SVI}(\mathrm{ml} / \mathrm{kg} /$ beat $)$ & $\begin{array}{l}0.91 \\
(.36)\end{array}$ & $\begin{array}{l}0.87 \\
(.25)\end{array}$ & $\begin{array}{c}0.72 \\
(.19)\end{array}$ \\
\hline $\mathrm{SVRI}(\mathrm{mm} \mathrm{Hg} / \mathrm{ml} / \mathrm{kg} / \mathrm{min})$ & $\begin{array}{l}0.73 \\
(.23)\end{array}$ & $\begin{array}{l}0.85 \\
(.25)\end{array}$ & $\begin{array}{l}0.83 \\
(.23)\end{array}$ \\
\hline PVRI (mm Hg/ml $/ \mathrm{kg} / \mathrm{min})$ & $\begin{array}{l}0.095 \\
(.07)\end{array}$ & $\begin{array}{c}0.118 \\
(.05)\end{array}$ & $\begin{array}{l}0.125 \\
(.05)\end{array}$ \\
\hline $\mathrm{pH}$ & $\begin{array}{l}7.49 \\
(.11)\end{array}$ & $\begin{array}{l}7.49 \\
(.03)\end{array}$ & $\begin{array}{l}7.49 \\
(.05)\end{array}$ \\
\hline $\mathrm{PaO}_{2}$ (torr) & $\begin{array}{l}250 \\
(43)\end{array}$ & $\begin{array}{l}265 \\
(34)\end{array}$ & $\begin{array}{l}242 \\
(27)\end{array}$ \\
\hline $\mathrm{PaCO}_{2}$ (torr) & $\begin{array}{l}27.6 \\
(8.7)\end{array}$ & $\begin{array}{l}27.0 \\
(4.1)\end{array}$ & $\begin{array}{l}27.9 \\
(2.9)\end{array}$ \\
\hline Base excess (U) & $\begin{array}{c}+1.2 \\
(3.5)\end{array}$ & $\begin{array}{c}-0.8 \\
(2.4)\end{array}$ & $\begin{array}{c}+0.02 \\
(2.7)\end{array}$ \\
\hline Hematocrit & $\begin{array}{l}31.0 \\
(4.0)\end{array}$ & $\begin{array}{l}27.0 \\
(4.5)\end{array}$ & $\begin{array}{l}32.2 \\
(4.8)\end{array}$ \\
\hline
\end{tabular}
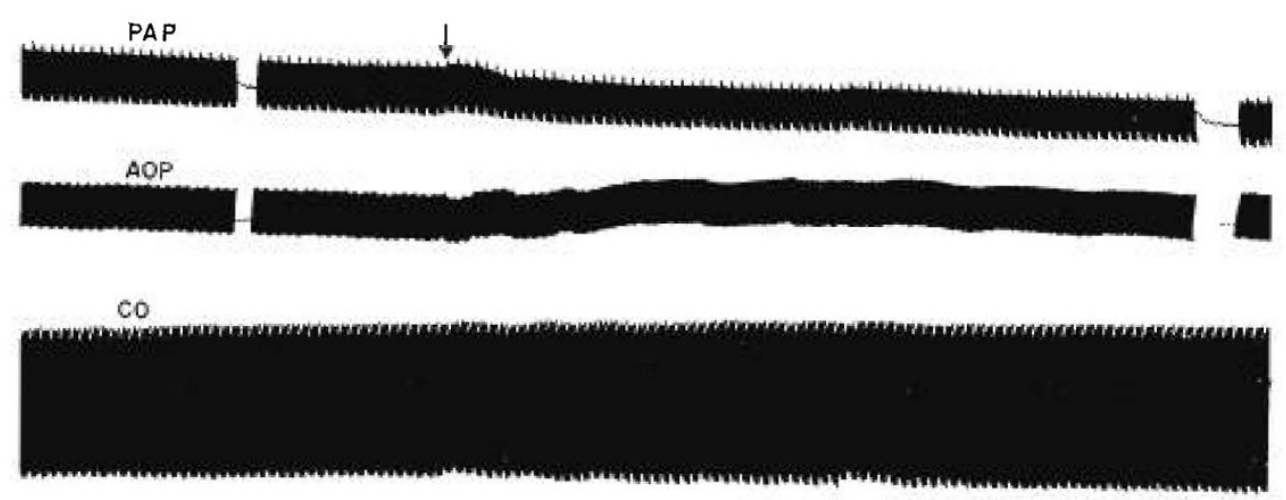

$1 \mathrm{~min}$

Fig. 1. Time course of changes in PAP, AOP, and CO during EPI infusion for a single septic piglet in group $1 . \mathrm{EPI}$ infusion $(3.5 \mu \mathrm{g} / \mathrm{kg} / \mathrm{min})$ begun at arrow. AOP rose from 81 to $118 \mathrm{~mm} \mathrm{Hg}$, PAP fell from 25 to $23 \mathrm{~mm} \mathrm{Hg}$, and CO rose from 710 to $830 \mathrm{ml} / \mathrm{min}$ during EPI administration. 
Table 2. Hemodynamic changes after infusion of GBS or placebo in piglets [mean $(S D)]$

\begin{tabular}{|c|c|c|c|}
\hline & $\begin{array}{c}\text { Group 1 } \\
(n=6) \\
\text { After GBS }\end{array}$ & $\begin{array}{c}\text { Group } 2 \\
(n=6) \\
\text { After GBS }\end{array}$ & $\begin{array}{c}\text { Group 3 } \\
(n=6) \\
\text { After placebo }\end{array}$ \\
\hline $\mathrm{AOP}(\mathrm{mm} \mathrm{Hg})$ & $\begin{array}{c}+3.3 \\
(7.0)\end{array}$ & $\begin{array}{l}+2.0 \\
(10.8)\end{array}$ & $\begin{array}{c}+0.66 \\
(6.4)\end{array}$ \\
\hline PAP (mm Hg) & $\begin{array}{c}+22.4^{*} \dagger \\
(2.8)\end{array}$ & $\begin{array}{c}+21.7 \ddagger \S \\
(9.6)\end{array}$ & $\begin{array}{c}+1.5 \\
(3.9)\end{array}$ \\
\hline $\mathrm{CI}(\mathrm{ml} / \mathrm{min} / \mathrm{kg})$ & $\begin{array}{c}-43.4^{*} \dagger \\
(17.6)\end{array}$ & $\begin{array}{c}-32.2 \S \\
(17.1)\end{array}$ & $\begin{array}{r}-14.0 \| \\
(9.6)\end{array}$ \\
\hline HR (beats/min) & $\begin{array}{c}+5.3 \\
(15.1)\end{array}$ & $\begin{array}{l}+2.0 \\
(12.7)\end{array}$ & $\begin{array}{c}+10.3 \\
(20.2)\end{array}$ \\
\hline $\operatorname{SVI}(\mathrm{ml} / \mathrm{kg} /$ beat $)$ & $\begin{array}{r}-0.29 \dagger \\
(.17)\end{array}$ & $\begin{array}{c}-0.27 \S \\
(.14)\end{array}$ & $\begin{array}{r}-0.12 \| \\
(.05)\end{array}$ \\
\hline SVRI $(\mathrm{mm} \mathrm{Hg} / \mathrm{ml} / \mathrm{kg} / \mathrm{min})$ & $\begin{array}{r}+0.41 \dagger \\
(.30)\end{array}$ & $\begin{array}{r}+0.42 \\
(.41)\end{array}$ & $\begin{array}{r}+0.13 \| \\
(.08)\end{array}$ \\
\hline PVRI (mm Hg/ml/kg/min) & $\begin{array}{c}+0.31^{*} \dagger \\
(.19)\end{array}$ & $\begin{array}{c}+0.35 \div \S \\
(.21)\end{array}$ & $\begin{array}{r}+0.03 \\
(.05)\end{array}$ \\
\hline
\end{tabular}

$* p<0.05$ group 1 vs group 3 .

$\dagger p<0.05$ group 1 pre-GBS $v s$ group 1 post-GBS.

$\$ p<0.05$ group 2 vs group 3 .

$\S p<0.05$ group 2 pre-GBS $v s$ group 2 post-GBS.

$\| p<0.05$ group 3 preplacebo $v s$ group 3 postplacebo.

Table 3. Hemodynamic changes after infusion of epinephrine during $G B S$ in piglets [mean $(S D)$ ]

\begin{tabular}{|c|c|c|c|}
\hline & \multicolumn{3}{|c|}{ EPI dose } \\
\hline & $\begin{array}{c}3.5 \\
\mu \mathrm{g} / \mathrm{kg} / \mathrm{min}\end{array}$ & $\begin{array}{c}7.0 \\
\mu \mathrm{g} / \mathrm{kg} / \mathrm{min}\end{array}$ & $\begin{array}{c}15 \\
\mu \mathrm{g} / \mathrm{kg} / \mathrm{min}\end{array}$ \\
\hline $\mathrm{AOP}(\mathrm{mm} \mathrm{Hg})$ & $\begin{array}{l}+18.5^{*} \dagger \ddagger \\
(11.6)\end{array}$ & $\begin{array}{l}+31.0^{*} \dagger \ddagger \\
(10.0)\end{array}$ & $\begin{array}{l}+45.0^{*} \dagger \ddagger \\
(18.4)\end{array}$ \\
\hline PAP (mm Hg) & $\begin{array}{c}-5.2^{*} \ddagger \\
(3.6)\end{array}$ & $\begin{array}{c}-6.3^{*} \dot{\dagger} \\
(5.5)\end{array}$ & $\begin{array}{l}-8.2^{*} \dagger+ \\
(4.4)\end{array}$ \\
\hline $\mathrm{Cl}(\mathrm{cc} / \mathrm{min} / \mathrm{kg})$ & $\begin{array}{l}+4.6^{*} \dagger+ \\
(3.5)\end{array}$ & $\begin{array}{c}+3.9^{*} \\
(10.8)\end{array}$ & $\begin{array}{c}-13.4 \\
(41.8)\end{array}$ \\
\hline HR (beats/min) & $\begin{array}{l}+7.5 \\
(23.2)\end{array}$ & $\begin{array}{c}+26.7 \\
(59.0)\end{array}$ & $\begin{array}{l}-5.2 \\
(85.4)\end{array}$ \\
\hline $\mathrm{SVI}$ (cc/kg/beat) & $\begin{array}{r}-0.013 \\
(.099)\end{array}$ & $\begin{array}{r}-0.097 \\
(.18)\end{array}$ & $\begin{array}{r}-0.067 \\
(.37)\end{array}$ \\
\hline SVRI $(\mathrm{mm} \mathrm{Hg} / \mathrm{cc} / \mathrm{kg} / \mathrm{min})$ & $\begin{array}{c}+0.144 \ddagger \\
\quad(.14)\end{array}$ & $\begin{array}{r}+0.25 \ddagger \\
(.20)\end{array}$ & $\begin{array}{c}+0.44 \dagger \ddagger \\
\quad(.33)\end{array}$ \\
\hline PVRI (mm Hg/cc/kg/min) & $\begin{array}{c}-0.066^{*} \ddagger \\
(.06)\end{array}$ & $\begin{array}{c}-0.080^{*} \\
(.09)\end{array}$ & $\begin{array}{c}-0.079^{*} \\
(.11)\end{array}$ \\
\hline
\end{tabular}

$* p<0.05$ vs group 2.

$\dagger p<0.05$ vs group 3 .

$\ddagger p<0.05$ vs pre-EPI value.

dent's unpaired two-tailed $t$ test with Bonferroni correction for subsequent pairwise comparisons. Statistical significance was accepted at the $p<0.05$ level.

\section{RESULTS}

Table 1 displays baseline hemodynamic and blood gas values for experimental animals in each group. The groups did not differ significantly from each other in any parameter. These observations are comparable to data previously reported for piglets using other laboratory models $(11,12)$.

Table 2 displays hemodynamic changes during GBS infusion (groups 1 and 2) and comparable data for piglets who received placebo (group 3). There were no significant differences in response to GBS between groups 1 and 2. Overall, GBS infusion elevated PAP by $22.0 \pm 6.7 \mathrm{~mm} \mathrm{Hg}$ and elevated PVRI by 0.33 $\pm 0.19 \mathrm{~mm} \mathrm{Hg} / \mathrm{ml} / \mathrm{kg} / \mathrm{min}$, while CI fell by $37.8 \pm 17.6 \mathrm{ml} / \mathrm{kg} /$ min and SVI fell by $0.28 \pm 0.15 \mathrm{ml} / \mathrm{kg} / \mathrm{beat}$. GBS did not differ from placebo in its effects on AOP, SVRI, and HR.

Figure 1 depicts the effect of EPI at $3.5 \mu \mathrm{g} / \mathrm{kg} / \mathrm{min}$ on PAP, AOP, and CO for a single septic piglet in group 1. Two points are readily appreciated. First, AOP rose immediately on administration of EPI while PAP fell. Second, selective elevation of AOP versus PAP was achieved without a fall in $\mathrm{CO}$. The responses of AOP, PAP, and CO reached steady state within $5 \mathrm{~min}$ of the onset of EPI infusion.

Table 3 displays the effects of EPI at three doses during GBS sepsis in piglets. At all doses, AOP rose significantly compared to both groups 2 and 3 , while PAP and PVRI fell significantly. At 3.5 and $7.0 \mu \mathrm{g} / \mathrm{kg} / \mathrm{min}$, but not at $15 \mu \mathrm{g} / \mathrm{kg} / \mathrm{min}$, CI rose significantly compared to group 2 . Changes in HR and SVI did not differ among groups 1, 2, and 3 comparing EPI versus placebo infusion. No significant differences in any variable were noted after placebo infusion, comparing septic (group 2) and nonseptic (group 3) piglets (not shown).

Blood gas values were equivalent among piglets in each group at the completion of the experimental protocol. Neither metabolic acidosis nor hypoxemia was observed in any test group $\mathrm{pH}$ $=7.33 \pm 0.12,7.41 \pm 0.08,7.44 \pm 0.04 ; \mathrm{PaO}_{2}=234 \pm 38,274$ $\pm 36,191 \pm 59 ; \mathrm{PaCO}_{2}=34.6 \pm 10.7,29.4 \pm 4.7,26.6 \pm 1.9$; base excess $=-4.3 \pm 4.4,-4.8 \pm 3.6,-3.4 \pm 2.3$ for groups 1 , 2 , and 3 , respectively).

\section{DISCUSSION}

In human neonates with pulmonary hypertension, when PAP approaches the level of AOP right-to-left shunting of blood through the foramen ovale or ductus arteriosus may occur (14). In these cases, selective elevation of AOP versus PAP would impede right-to-left shunts. We report herein that EPI raised AOP while reducing PAP and preserving $\mathrm{CO}$ in piglets with sepsis-induced pulmonary hypertension.

The elevations of AOP and SVRI induced by EPI increased significantly with higher EPI doses. However, for EPI at $3.5 \mu \mathrm{g} /$ $\mathrm{kg} / \mathrm{min}$ the rise in AOP was associated with a significant increase in both CI and SVRI, whereas at both 7.0 and $15.0 \mu \mathrm{g} / \mathrm{kg} / \mathrm{min}$ the rise in AOP was accounted for entirely by an elevation in SVRI. In addition, CI fell in three piglets when EPI was administered at $15 \mu \mathrm{g} / \mathrm{kg} / \mathrm{min}$, whereas CI did not fall in any piglet when EPI was administered at $3.5 \mu \mathrm{g} / \mathrm{kg} / \mathrm{min}$. These results may suggest that at higher EPI doses the vasoconstrictor effects of EPI predominated over its inotropic effects and the myocardium was unable to maintain $\mathrm{CI}$ in the face of the increased afterload.

Previous reports of adverse effects during catecholamine infusions have documented increased intrapulmonary shunts and metabolic acidosis (13). We found no evidence for these adverse effects during EPI infusion in these septic piglets. Changes in $\mathrm{PaO}_{2}$ and arterial base excess did not differ comparing piglets who received GBS + EPI (group 1), GBS + placebo (group 2), or placebo alone (group 3).

Most previous approaches to PPHN, either in humans or experimental animal models, have focused on impeding the right-to-left shunt by reducing PAP selectively, i.e. lowering PAP more than AOP for any given intervention. These approaches have, on the whole, been unsuccessful. Tolazoline, acetylcholine, $\mathrm{PGE}_{1}, \mathrm{PGD}_{2}$, chlorpromazine, and amrinone have all been found to reduce pulmonary and systemic blood pressures equally under various conditions of normal and elevated PAP in humans and experimental animals $(4-7,10,14-16)$. Prostaglandin inhibitors 
and leukotriene antagonists have been reported to reduce elevated PAP induced by GBS or hypoxia in lambs $(17,18)$ and piglets (19-21). However, none of these compounds is currently licensed for use in human newborns with pulmonary hypertension.

Phenylephrine has been reported by us to raise AOP selectively compared to PAP in septic piglets (8). However, this effect was invariably accompanied by a significant reduction in CI. We are aware of no previous reports of the concurrent effects of EPI on AOP and PAP during pulmonary hypertension. Norepinephrine has been reported to raise AOP and PAP to an equal extent in fetal lambs $(22,23)$. In contrast, dopamine has been shown to elevate PAP more than AOP in newborn lambs with normal PAP and lambs with hypoxia-induced pulmonary hypertension $(24,25)$. Consequently, and despite its current popularity, some authors have suggested caution in the use of dopamine in neonatal pulmonary hypertensive states (26).

The relevance of this piglet model of GBS sepsis to infected human infants has been recognized previously $(7,8,19)$. In addition, similar responses of piglets and human infants to catecholamine infusions (epinephrine, norepinephrine, isoproterenol, phenylephrine) have previously been reported $(11,12$, 27). Nevertheless, significant hemodynamic distinctions exist between these septic piglets and infected human infants. PA pressures in the piglets, although markedly elevated after GBS, never approached systemic levels, a phenomenon that occurs commonly in septic human newborns with persistent fetal circulation $(1,28)$. No piglet was hypoxemic at any time during these experiments, in contrast to the severe arterial desaturation frequently observed in human infants with sepsis-induced pulmonary hypertension. The foramen ovale and ductus arteriosus, open in human neonates with persistent fetal circulation, were closed in our piglets, none of whom was younger than 5 days. The lowest dose of EPI administered in these experiments (3.5 $\mu \mathrm{g} / \mathrm{kg} / \mathrm{min}$ ) was considerably higher than currently recommended for use in human newborns (13). These differences make extrapolation of data from 1- to 5-wk-old piglets to septic human infants necessarily tentative.

In sum, we report that EPI at $3.5,7.0$, and $15 \mu \mathrm{g} / \mathrm{kg} / \mathrm{min}$ raised AOP and SVRI while reducing PAP and PVRI in piglets with GBS-induced pulmonary hypertension. CI did not fall during EPI infusion. If these observations can be extrapolated to human neonates with sepsis-induced pulmonary hypertension, selective elevation of systemic blood pressure may become a feasible clinical strategy to impede the right-to-left shunting of blood characteristic of this disorder. These extrapolations will require extremely cautious clinical evaluation.

\section{REFERENCES}

1. Peckham GJ, Fox WW 1978 Physiologic factors affecting pulmonary artery pressure in infants with persistent pulmonary hypertension. J Pediatr 93:1005-1010

2. Fox WW, Duara S 1983 Persistent pulmonary hypertension in the neonate: Diagnosis and management. J Pediatr 103:505-514

3. Gersony WM 1984 Neonatal pulmonary hypertension: pathophysiology, classification, and etiology. Clin Perinatol 11:517-524

4. Goetzman BW, Sunshine P, Johnson JD, Wennberg RP, Hackel A, Merten
DF, Bartoletti AL, Silverman NH 1976 Neonatal hypoxia and pulmonary vasospasm: response to tolazoline. J Pediatr 89:617-620

5. Kulik TJ, Lock JE 1984 Pulmonary vasodilator therapy in persistent pulmonary hypertension of the newborn. Clin Perinatol 11:693-702

6. Lock JE, Coceani F, Olley PM 1979 Direct and indirect pulmonary vascular effects of tolazoline in the newborn lamb. J Pediatr 95:600-605

7. Meadow WL, Meus PJ 1984 Hemodynamic consequences of tolazoline infusion in neonatal group B Streptococcal bacteremia: an animal model. Pediatr Res 18:960-965

8. Meadow WL, Rudinsky BF, Strates E Effects of phenylephrine on systemic and pulmonary artery pressure during sepsis-induced pulmonary hypertension in piglets. Dev Pharm Ther (in press)

9. Gregory GA, Lister G, Heymann MA 1984 The effects of tolazoline on the distribution of cardiac output in normoxemic and hypoxemic lambs. Pediatr Res 18:896-900

10. Tripp ME, Drummond WH, Heymann MA, Rudolph AM 1980 Hemodynamic effects of pulmonary arterial infusion of vasodilators in newborn lambs. Pediatr Res 14:1311-1315

11. Buckley NM, Gootman PM, Yellin EL, Brazeau P 1979 Age-related cardiovascular effects of catecholamines in anesthetized piglets. Circ Res 45:282292

12. Gootman PM, Buckley NM, Crane LA, Buckley BJ, Gootman N 1978 Integrated cardiovascular responses to combined somatic afferent stimulation in newborn piglets. Biol Neonate 34:187-198

13. Perkin RM, Levin DL 1982 Shock in the pediatric patient: Part Two. Therapy. J Pediatr 101:319-331

14. Philips JB III, Lyrene RK, McDevitt M, Perlis W, Satterwhite C, Cassidy G 1983 Prostaglandin D2 inhibits hypoxic pulmonary vasoconstriction in neonatal lambs. J Appl Physiol 54:1585-1589

15. Soifer SJ, Morin FC, Heymann MA 1982 Prostaglandin D2 reverses induced pulmonary hypertension in the newborn lamb. J Pediatr 100:458-463

16. Soifer SJ, Clyman RI, Heymann MA 1985 Prostaglandin D2 does not lower pulmonary arterial pressure or improve oxygenation in infants with persistent pulmonary hypertension syndrome (PPHN). Pediatr Res 19:365A(abstr)

17. Rojas J, Larsson LE, Ogletree ML, Brigham KL, Stahlman MT 1983 Effects of cyclooxygenase inhibition on the response to group B Streptococcal toxin in sheep. Pediatr Res 17:107-110

18. Schreiber MD, Heymann MA, Soifer SJ 1985 Leukotriene inhibition prevents and reverses hypoxic pulmonary vasoconstriction in newborn lambs. Pediat Res 19:437-441

19. Runkle B, Goldberg RN, Streitfeld MM, Clark MR, Buron E, Setzer ES, Bancalari E 1984 Cardiovascular changes in Group B Streptococcal sepsis in the piglet: response to indomethacin and relationship to prostacyclin and thromboxane A2. Pediatr Res 18:874-879

20. Goldberg RN, Suguihara C, Steitfeld MM, Runkle B, Bancalari E 1985 Effects of leukotriene antagonist FPL57231 on the early hemodynamic manifestations of group B beta Streptococcal sepsis (GBS) in piglets. Pediatr Res 19:342A(abstr)

21. Philips JB III, Lyrene RK 1984 Prostaglandins, related compounds, and the perinatal pulmonary circulation. Clin Perinatol 11:565-579

22. Assali NS, Brinkman CR III, Woods JR, Dandavino A, Nuwayhid B 1977 Development of neurohumoral control of fetal, neonatal, and adult cardiovascular functions. Am J Obstet Gynecol 129:748-759

23. Nuwayhid B, Brinkman CR III, Su C, Bevan JA, Assali NS 1975 Systemic and pulmonary hemodynamic responses to adrenergic and cholinergic agonists during fetal development. Biol Neonate 26:301-317

24. Drummond WH 1984 Use of cardiotonic therapy in the management of infants with PPHN. Clin Perinatol 11:715-728

25. Williams BJ, Drummond WH 1983 The effect of alpha-adrenergic blockade on the pulmonary vascular response to dopamine in neonatal lambs. Pediatr Res 17:464-467

26. Kliegman R, Fanaroff AA 1978 Caution in the use of dopamine in the neonate. J Pediatr 93:540-541

27. Jarenwattananon M, Gootman N, Buckley BJ, Kaplan NA, Griswold PG, Gootman PM 1985 Effects of a calcium antagonist on the cardiovascular responses to an alpha 1 adrenoceptor agonist in developing swine. Pediatr Res 19:174A(abstr)

28. Drummond WH, Gregory GA, Heymann MA, Phibbs RA 1981 The independent effects of hyperventilation, tolazoline, and dopamine on infants with persistent pulmonary hypertension. J Pediatr 98:603-611 